\title{
Experimental Pseudomonas anguilliseptica infection in turbot Psetta maxima (L.): a histopathological and immunohistochemical study
}

\author{
G.E. Magi, ${ }^{1}$ S. Lopez-Romalde, ${ }^{2}$ B. Magariños, ${ }^{2}$ J. Lamas, ${ }^{3}$ A.E. Toranzo, ${ }^{2}$ J.L. Romalde ${ }^{2}$
}

${ }^{1}$ Dipartimento di Scienze Veterinarie, Facoltà di Medicina Veterinaria, Università di Camerino, Matelica (MC), Italy; ${ }^{2}$ Departemento de Microbiología y Parasitología and ${ }^{3}$ Departamento de Biología Celular y Ecología, Facultad de Biología-CIBUS, Universidad de Santiago, Santiago de Compostela, Spain

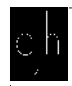

(C)2009 European Journal of Histochemistry

Experimental infection with Pseudomonas anguilliseptica was performed both by intraperitoneal (i.p.) and bath route on juvenile turbot (Psetta maxima) in order to evaluate the pathology induced. Turbot was found to be sensitive to i.p. challenge $\left(1.7 \times 10^{6} \mathrm{CFU} /\right.$ fish) but no to bath exposure. The i.p. challenge induced septicaemic infection and mortality. Externally, moribund fish showed distended abdomen and pale areas at day 9 . The gross pathological internal signs present were abundant ascitic fluid in the peritoneal cavity, pale and enlarged spleen, pale and friable liver, and congestive and dilated gut with yellowish exudates. On histopathological examination, bacterial invasion was common in all the tissues studied but the most prominent pathological changes were observed in gut, spleen and kidney after 7 day with features of necrosis. The immunohistochemical findings support the widespread localization of the bacteria after the i.p. injection since the $P$. anguilliseptica was detected in spleen from day 1 post injection, in liver, kidney and gut from day 4, in muscle from day 7 and in brain from day 9 . The difficulties in infecting healthy fish by bath challenge can be explained by the opportunistic nature of this pathogen.

Key words: turbot, Psetta maxima, Pseudomonas anguilliseptica, experimental infection, histopathology, immunohistochemistry.

Correspondence: Gianenrico Enrico Magi,

Dipartimento di Scienze Veterinarie, Sezione di Patologia Animale, Profilassi e Igiene degli Alimenti.

Via Circonvallazione 93/95 62024 Matelica (MC).

Tel.: +39.0737.403424.

Fax: +39.0737.403402.

E-mail: gianenrico.magi@unicam.it

\section{Paper accepted on May 20, 2009}

European Journal of Histochemistry 2009; vol. 53 issue 2 (April-June): 73-80
$P$ seudomonas anguilliseptica is considered a pathogen that affects a variety of fish species cultured in marine and brackish waters (Austin and Austin 1999; Toranzo et al., 2005). The microorganism was originally described as the causative agent of the "red spot disease", a hemorrhagic septicemia also known as "sekiten-byo" that has occurred in Japanese eel Anguilla japonica cultured in Japan (Wakabayashi and Egusa, 1972). Since then this pathogen has been recorded in other cultured and wild fish species, such as European eel Anguilla anguilla (Stewart et al., 1983), blackhead seabream Acanthopagrus schlegeli, ayu Plecoglossus altivelis (Nakai et al., 1985), Atlantic salmon Salmo salar, sea trout Salmo trutta, rainbow trout Oncorhynchus mykiss, whitefish Coregonus sp. (Wiklund and Bylund, 1990), Baltic herring Clupea harengus membras (Lönnström et al., 1994), sea bass Dicentrarchus labrax (Berthe et al., 1995), striped jack Pseudocaranx dentex (Kusuda et al., 1995), and orange-spotted grouper Epinephelus coioides (Al-Marzouk, 1999).

In the last decade, this pathogen has been isolated during the cold periods from turbot (Psetta maxima), another major marine fish species cultured in Southern Europe (López-Romalde et al., 2003a), from black spot seabream Pagellus bogaraveo (López-Romalde et al. 2003b) and from cod Gadus morhua (Ferguson et al., 2004). Moreover, different microbiological studies have associated infection by $P$. anguilliseptica with the etiology of several outbreaks of "winter disease", a pathological condition affecting gilthead seabream reared in Southern Europe during the winter season (Berthe et al., 1995; Dómenech et al., 1997, 1999; López-Romalde et al., 2003a). Nevertheless, various authors consider the "winter disease" as a multifactorial syndrome associated with cold water temperature and stressful environmental conditions (Tort et al., 1998; Contessi et 
al., 2006). Lesions and clinical signs of $P$. anguilliseptica infection are variable among fish species. Few descriptions of the histopathological changes caused by $P$. anguilliseptica can be found in the literature. Pathology of $P$. anguilliseptica infection has been described for Japanese and European eels (Miyazaki and Egusa, 1977; Ellis et al., 1983) and cod (Ferguson et al., 2004), but not for turbot. Therefore, the aim of this study was to describe the pathology induced by $P$. anguilliseptica in turbot and to analyze its similarity with that of other fish species.

\section{Material and Methods}

\section{Bacteria}

A virulent strain of $P$. anguilliseptica (AZ197.1) originally isolated from diseased turbot during a natural epizootic at a Spanish farm was used in this study. The lethal dose (LD50) of the strain for this species was $1 \times 10^{6} \mathrm{CF}$ U/fish (LópezRomalde, 2005). Cultures were stored frozen at $-70^{\circ} \mathrm{C}$ in Tryptic Soy Broth (TSB-1) supplemented with $1 \% \mathrm{NaCl}$ and containing $15 \%(\mathrm{v} / \mathrm{v})$ glycerol until used.

\section{Fish}

Turbot, with a mean weight of about 15-20 g (age 4 months) were used in the experiment. The fish had no history of disease and were maintained at the aquarium facilities of the University of Santiago de Compostela during the course of the experiments (20 days). using 350 litres flat bottom tanks with closed system and with aerated seawater at $11 \pm 1^{\circ} \mathrm{C}$. Prior to the experiments fish were checked to be free of $P$. anguilliseptica by classical bacteriological and PCR procedures (López-Romalde et al., 2003a; Romalde et al., 2004)

\section{Challenge}

Two different challenge procedures were carried out; injection challenge and bath challenge Group of 25 turbot was challenged by intraperitoneal (i.p.) injection of $0.1 \mathrm{~mL}$ of $P$. anguilliseptica bacterial suspension with a dose of $1.7 \times 10^{6} \mathrm{CFU}$ $\mathrm{mL}^{-1}$. Immersion challenge was carried out by bathing a group of 25 fish in a starting suspension of $10^{10} \mathrm{CFU} \mathrm{I^{-1 }}$ for 30 minutes. As a control, 25 fish were injected with $0.1 \mathrm{~mL}$ of phosphate- buffered saline (PBS) or immersed in sterile seawater. The fish were observed for 20 days. Bacteria for the challenge were grown for $48 \mathrm{hrs}$ at $21 \pm 1^{\circ} \mathrm{C}$ in Columbia sheep blood agar (CBA; Oxoid, Ltd., Madrid). The bacteria was harvested and washed twice in sterile PBS at $1500 \mathrm{~g}$ for 10 $\min$ at $5^{\circ} \mathrm{C}$ and resuspended in sterile PBS. The water temperature during the challenges was of $11^{\circ} \mathrm{C}$. All dead or moribund fish and all fish still living on day 20 post infection were subjected to bacteriological and histopathological examinations.

\section{Pathology and histology}

Clinical signs, gross pathology and deaths were recorded daily. For histological examination 3 fish from each group were randomly sampled at 6 hrs and at 1, 4, 7 and 9 days post-infection. The remaining fish were collected when they became moribund or dead as well as at the end of the experiment at day 20. Samples of skin, muscle, gills, kidney, liver, spleen, gut and brain were fixed in $10 \%$ phosphate buffered formalin for $48 \mathrm{hrs}$, embedded in paraffin wax, sectioned at $5 \mu \mathrm{m}$ and stained with haematoxylin and eosin and Giemsa. The infection was established by re-isolation of the bacterium from fish sampled and mortalities were only considered to be a result of the inoculated strain if the bacterium was recovered in pure culture from the internal organs of dead fish.

\section{Bacteriology}

Samples of spleen, kidney, brain and liver obtained from one fish at each sampling time (6 hrs; 1, 4, 7 and 9 days post-infection) and from all moribund/dead fish were spread on Columbia sheep blood agar and incubate for 3 days at $21 \pm 1^{\circ} \mathrm{C}$. Identification of bacteria on blood agar was confirmed by using physiological and biochemical plate and tube tests (Lopez-Romalde et al., 2003a), as well as by slide agglutination using specific rabbit antisera (Toranzo et al., 1987) and by PCR method (Romalde et al., 2004).

\section{Immunohistochemistry}

Immunohistochemical examination was performed on the same tissues sampled for histopathological evaluation in order to study the distribution of the bacteria. Deparrafinized sections ( $3 \mu \mathrm{m}$ thick) were incubated with $5 \%$ bovine serum albumin ( $w / v, B S A$, Sigma) in phosphate- 
buffered saline (PBS) for 20 min to block nonspecific binding sites. Tissue sections were then incubated for 2 hrs with a polyclonal antibody raised in rabbit against a Spanish strain of $P$. anguilliseptica (TW-P1) isolated from gilthead seabream. The primary antibodies were diluted $1: 250$ in PBS containing $0.1 \%$ crystalline bovine serum albumin (BSA). Antibody labelling was revealed with alkaline phosphatase conjugate goat anti-rabbit IgG (Bio-Rad) diluted 1:500 with $0.1 \%$ BSA in PBS applied for 45 mins at room temperature as secondary antibodies. The enzymatic reaction was developed with a chromogen substrate composed of a solution of $\mathrm{N}, \mathrm{N}$ dimetylformamide $(0,7 \mathrm{ml}$, Sigma), distilled water $(0.3$ $\mathrm{mL}$ ) and Nitrobluetetrazolium (30 mg, Sigma) and a solution of $\mathrm{N}, \mathrm{N}$ dimetylformamide ( $1 \mathrm{~mL}$, Sigma) and 5-Bromo-4-Chloro-3-Indolylphosphate (15 mg, Sigma), both solutions were added to a carbonate buffer ( $100 \mathrm{~mL})$. The sections were incubated with the chromogen substrate in the dark and after washing in PBS, counterstained with eosin for $1 \mathrm{~min}$. As negative controls the primary antibody was substituted with PBS.

\section{Results}

\section{Mortality and gross pathology}

No mortalities occurred in turbot experimentally infected by bathing in a suspension containing $10^{10} \mathrm{CFU} \mathrm{I}^{-1} \mathrm{P}$. anguillisepitca. No mortalities occurred in control fish. Neither clinical signs of disease were recorded in the bath exposure group nor in the control groups. Mortalities of i.p. injected turbot started at day 9 after injection and $100 \%$ cumulative mortality was reached at day
11. Clinical signs and gross lesions were similar during the experiment in i.p. injected fish that showed anorexia and lethargy from day 5 after the injection. Externally, the fish that died at day 9 and 10 showed distended abdomen, resulting from ascites, and pale areas noticeable in the pigmented skin surface (Figure 1a). On internal examination, gross pathological findings were recorded only from day 7 when the fish sampled showed moderate ascitic fluid in the coelomic cavity, pale and enlarged spleen, pale and friable liver, and congestive and dilated gut with yellowish exudates. At day 9, the sampled and dead fish showed similar gross pathological finding but more severe (Figure 1b).

\section{Bacteriology}

Only bacteria with phenotypical characteristics identical to the $P$. anguilliseptica strain AZ 197.1 were reisolated in pure culture from kidney, brain, spleen and liver of all sampled and dead fish from the i.p. injected group. The reisolated strain agglutinated with the antiserum raised against the Spanish strain TW-P1. Identification of the isolate was confirmed by a specific PCR assay, where the strain rendered the expected fragment of 418 pb. No P. anguilliseptica or any other pathogenic bacteria were isolated at the end of the experiments from the organs of fish challenged by bath exposure or from the fish in the control groups.

\section{Histopathology}

None of the fish bath challenged suffered any histopathological change. Bacterial invasion was histologically observed in all the tissues studied from fish in the i.p. injected group. In this group, the most prominent pathological changes were

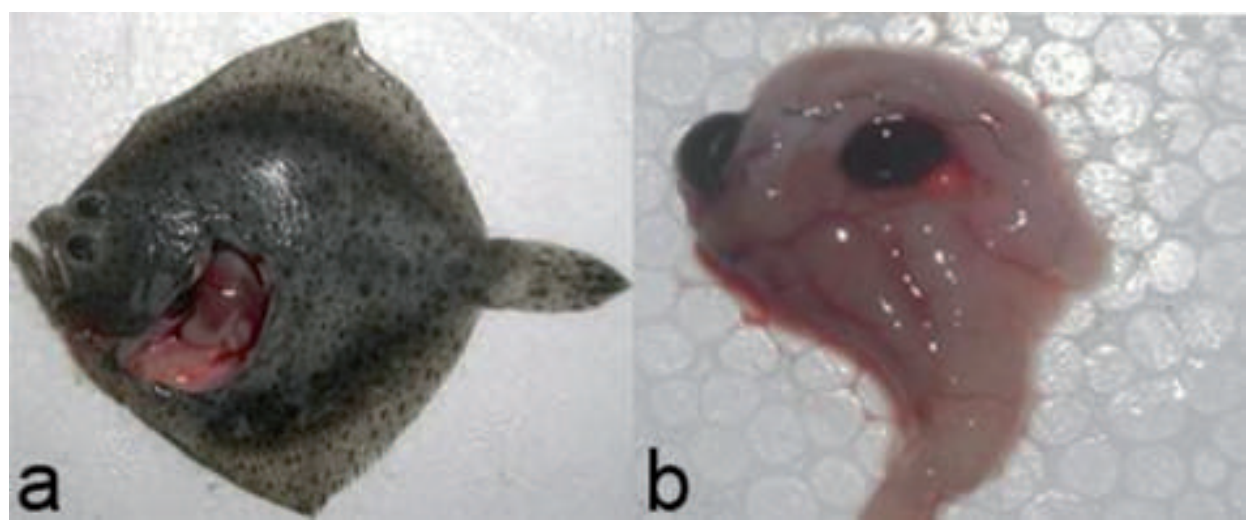

Figure 1. a) Skin pale areas and abundant ascitic fluid (day 9 after i.p. infection). b) Distended gut and enlarged spleen (day 9 after i.p. infection). 
observed in gut, spleen and kidney. The first changes in the gut were observed at day 4 post injection and included widespread hypertrophia of epithelial cells. At day 7, early necrotic changes of the mucosa together with oedema and presence of bacteria in the muscle layers were observed, although without increase in the number of inflammatory cells. The gut of moribund and dead fish showed severe diffuse mucosal necrosis with detachment of the mucosa from the inner layers; additionally, a large masses of bacteria spread throughout the tissue and clusters of cells debris were found in the lumen (Figure 2a).

The spleen was extensively colonized by $P$. anguilliseptica from day 1 until the end of the experimental infection. A marked oedema of large spleen areas was observed following the dissemination of the bacteria. Foci of necrosis were in the
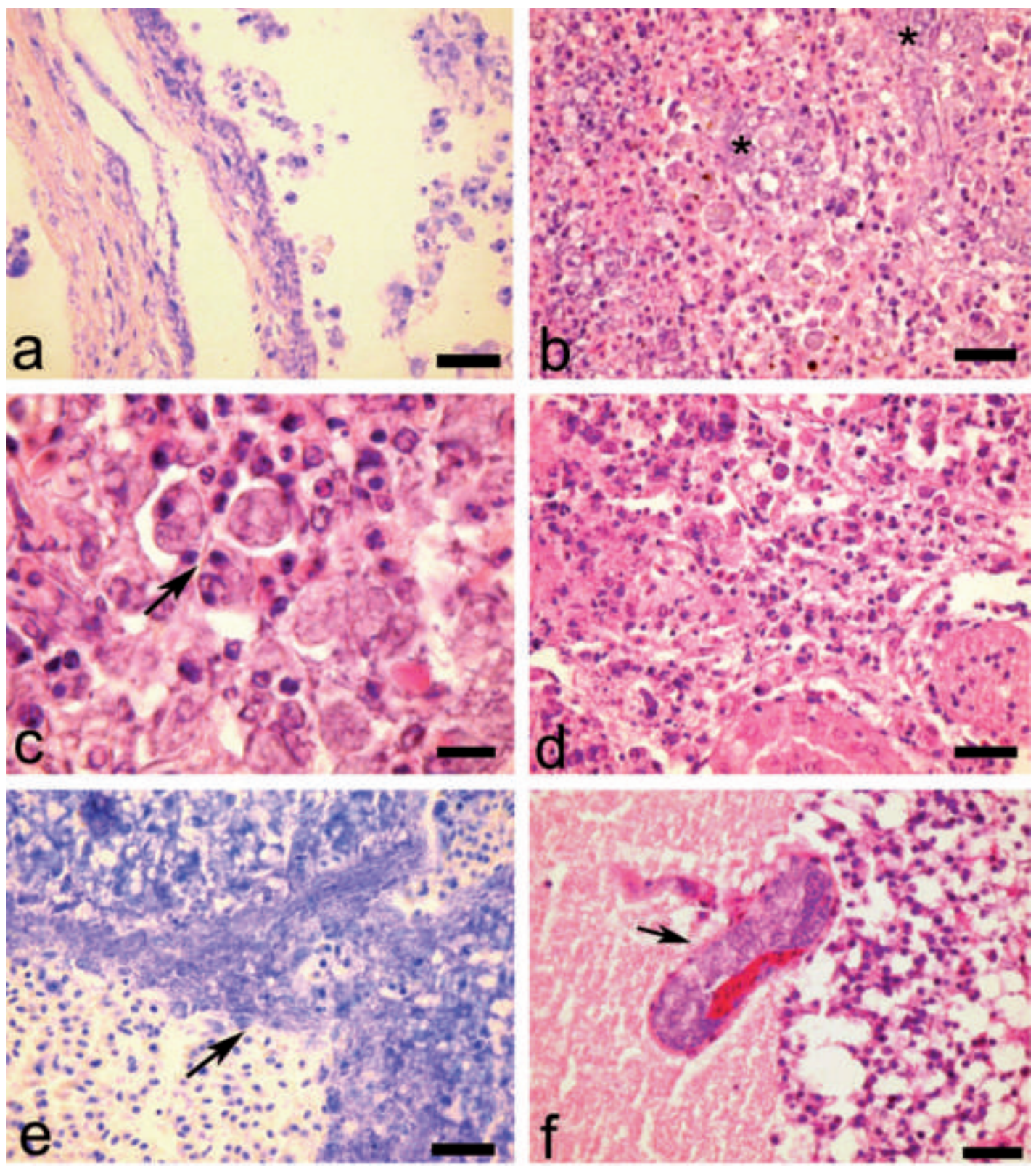

Figure 2. a) Necrosis and detachment of the gut mucosa (Giemsa) at day 7 after i.p. infection. Bar, $25 \mu \mathrm{m}$. b) Spleen: necrosis area with cluster of bacteria $\left(^{*}\right)(\mathrm{HE})$. Day 7 after i.p. infection. Bar, $25 \mu \mathrm{m}$. c) Spleen: numerous hypertrophied macrophages containing phagocytised erythrocytes, bacteria and cellular debris (arrow) (HE). Day 7 after i.p. infection. Bar, 12, 5 um. d) Kidney: extensive necrosis of hematopoietic cells (HE). Day 9 after i.p. infection. Bar, $25 \mu \mathrm{m}$. e) Liver: vasodilatation and clumps of bacteria in the vessel wall (arrow) (Giemsa). Day 7 after i.p. infection. Bar, $25 \mu \mathrm{m}$. f) Brain: masses of bacterial clumps being plugged in dilated vessel (arrow) (HE). Day 9 after i.p. infection. Bar, $25 \mu \mathrm{m}$. 
haematopoietic tissue and the cords, while sinusoids of the red pulp were strongly depleted (Figure 2b). The number of macrophage-like cells increased considerably, and these were hypertrophied and contained abundant phagocyted material (Figure 2c). The spleen of the dead fish at days 9 and 10 showed a disarchitecture of the organ, with diffused bacterial clusters.

In the kidney, the first change appeared at 4 day when dilatation of the sinusoids and slight inflammatory response underling the kidney capsule tissue were observed. At day, 7 , bacteria, oedema and focal necrosis were present in the interstitial kidney tissue. At days 9 and 10, the lesions were shown to be progressive and the dissemination of the bacteria caused extensive necrosis of hematopoietic cells (Figure $2 d$ ), as well as dilatation of peritubular capillaries and necrosis of the tubular epithelial cells and glomeruli

The liver lesions were not pronounced and were only detected in the fish sampled from day 7 , when slight sinusoidal congestion and areas of vasodilatation were observed. Clumps of bacteria were seen in vessels, mainly in the sinusoidal lumen (Figure 2e) and were usually associated with epatocellular degeneration.

In the brain no alterations were observed until day 7 . The brain of the fish sampled and dead at days 9 and 10 showed of bacterial aggregates being plugged in capillaries of the encephalon (Figure 2f).

In the muscle, bacterial clumps were observed in the perimysium surrounding the muscle fascicles from day 7 post infection. At days 9 and 10, $P$. anguilliseptica multiply and spread in the endomysium and occasionally invaded the fibers resulting in moderate myolysis. No leucocytic infiltration between muscle fibers was observed. No lesions were observed in gills.

\section{Immunohistochemistry}

No tissue stained with immunohistochemical for $P$. anguilliseptica was seen in the bath exposure group or in the control groups. A positive immunostaining was detected in spleen, gut, liver, kidney, muscle and brain of i.p. infected fish. The first organ positively labelled was the spleen, where free bacteria were present in the parenchyma from 6 hrs after infection (Figure $3 a$ ). In addition, a cytoplasmic immunostaining was detected in the macrophages from day 4 until the end of the experiment. The liver and kidney were positively immunolabelled from day 4 after experimental infection, at which time free bacteria were seen in vascular system and sinusoids. In the fish dead at days 9 and 10, positively stained bacteria surrounding the sinusoids were observed. At days 7 and 9, numerous immunolabelled bacteria were seen in the hematopoietic tissue and in the glomeruli.

In the gut, positively stained free bacteria were seen in all layers from day 4 after injection. Numerous immunopositive bacteria were seen in the epimysium surrounding the muscle fibers from day 7 after injection, occasionally the bacteria were observed inside the necrotic fibers (Figure $3 \mathrm{~b}$ ). In the brain, positively stained masses of bacteria were seen inside the dilated vessel of the fish died at days 9 and 10. Dead and moribund fish from day 7 after injection showed septicemia.

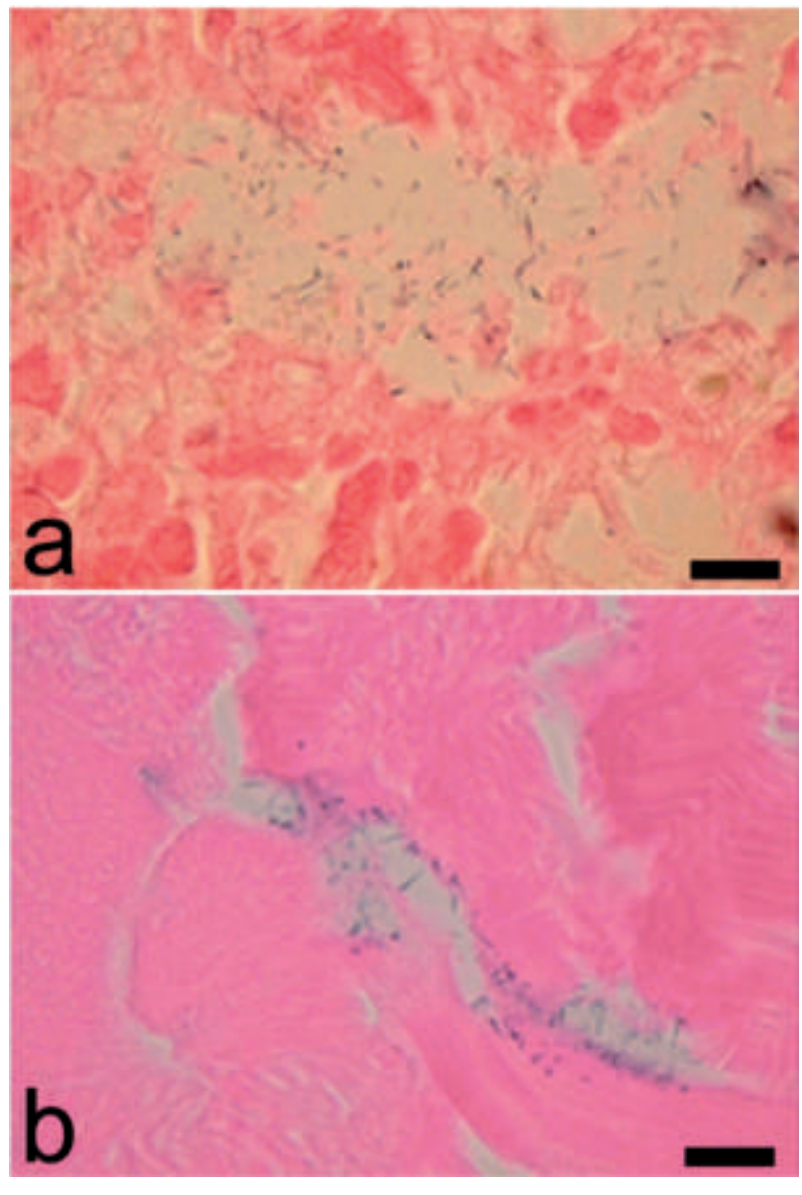

Figure 3. a) Spleen: immunostain positive for $\boldsymbol{P}$ anguilliseptica at 1 day after i.p. infection (IHC). Bar, $25 \mu \mathrm{m}$. b) Muscle: immunostain positive for $P$ anguilliseptica at day 7 after i.p. infection (IHC). Bar, $25 \mu \mathrm{m}$. 


\section{Discussion}

In this study the isolate of $P$. anguilliseptica was pathogenic for turbot experimentally infected by i.p. but not by immersion route. The i.p. challenge performed at a water temperature of $11 \pm 1^{\circ} \mathrm{C}$ resulted in a septicaemic infection, and all fish died within 11 days. No mortality or clinical/histopathological signs were observed in fish experimentally infected by bath.

Externally, the moribund and dead fish both showed distended abdomen and pale areas similarly to that described in sea-bream. However no petechial haemorrhages or keratitis were observed. This was probably due to the fact that the bacteria inoculated caused the death before the external lesions could appear (Domenech et al., 1997). In fact, although a dose similar to $D L_{50}$ was employed (López-Romalde, 2005), a 100\% mortality was obtained which can be explained either by different size of the fish used and/or by different familial sensibility.

The gross pathological internal signs of the dead and moribund fish were similar to those observed by Ellis et al. (1983) and Michel et al. (1992) in European eel naturally infected by $P$. anguilliseptica, and in naturally infected sea-bream (Domenech et al., 1997), i.e. presence of ascitic fluid in the coelmatic cavity, spleen pale and enlarged, liver pale and friable and, in a few cases, presence of petechial hemorrhages. Histologically, the most prominent pathological changes were observed in gut, spleen and kidney, where diffuse necrotic multifocal areas were observed. The histopathological findings observed in this study had characteristics of a peracute septicaemic disease characterized by systemic infection and necrotic changes. The lesions of the spleen, kidney and gut could be considered to be the cause of death. The immunohistochemical findings support the widespread localization of the bacteria after the i.p. infection since the $P$. anguilliseptica was detected in spleen after $6 \mathrm{hrs}$, in liver, kidney and gut from day 4 , in muscle from day 7 and in brain from day 9.

Histopathological lesions caused by $P$. anguilliseptica infection have been described in Japanese eel (Miyazaki and Egusa, 1977), European eel (Ellis et al., 1983), salmonid species (Wiklund and Bylund, 1990) and cod (Ferguson et al., 2004). Among these species the more intense and widespread lesions were observed in Japanese and European eel. In particular, the diseased Japanese eel had severe necrotic haemorrhagic changes affecting the spleen, kidney, liver, dermis, subcutaneous adipose tissue, vascular walls, bulbus arteriosus and heart.

It is well known that the route of experimental infection influence the onset and pathology of the disease. Normally the pathological changes seen in natural conditions or through bath/oral exposure differ from those observed in experimentally infected fish by i.p. and/or intramuscular challenges. These routes avoid the natural barriers of fish leading to a faster and less natural progression of the disease, in which the internal organs are more likely to be exposed. On the contrary with bath or co-habitation methods the fish are subjected to lower doses of bacteria over a longer period of time giving the different components of the immune system more time to respond to the infection. However, the difficulties in infecting healthy fish by bath challenge in this study could be related to opportunistic characteristics of this pathogen proved by the high DL50 of the strain in the i.p. challenge (López-Romalde, 2005). This finding supports the hypothesis that an outbreak of $P$. anguilliseptica infection in turbot is favoured by stress factors associated with intensive farming system.

In conclusion this is the first study carried out to describe the histopathological features induced in turbot after infection with $P$. anguilliseptica. The majority of the alterations observed were similar to those reported in other fish species were they had been infected with this pathogen either naturally or experimentally. Further studies, using infection routes mimicking the natural conditions (i.e. co-habitation, bath plus stressors), would help to confirm this hypothesis.

\section{Acknowledgement}

This work was supported in part by Grant AGL2006-13208-C02-00/ACU from the Ministerio de Educación y Ciencia (MEC), Spain.

\section{References}

Austin B, Austin DA. Epizootiology: Gram-negative bacteria. In: Austin $B$, Austin DA, eds. Bacterial fish pathogens: disease of farmed and wild fish. 3rd ed. Praxis Publishing Ltd, Chichester, England, 1999, pp. 235-6.

Al-Marzouk AE. Association of Pseudomonas anguilliseptica with 
mortalities in cultures marine orange-spotter grouper, Epinephelus cocides, in Kuwait. Fish Pathol 1999;34:167-8.

Berthe FJC, Michel C, Bernadet JF. Identification of Pseudomonas anguilliseptica isolated from several fish species in France. Dis Aquat Organ 1995;21:151-5.

Contessi B, Volpatti D, Gusmani L, Galeotti M. Evaluation of immunological parameters in farmed gilthead seabream, Sparus aurata L., before and during outbreaks of "winter syndrome". J Fish Dis 2006; 29:683-90.

Doménech A, Fernández-Garayzábal JF, Lawson P, García JA, Cutuli MT, Blanco M, et al. Winter disease outbreak in sea-bream (Sparus aurata) associated with Pseudomonas anguilliseptica infection. Aquaculture 1997;156:317-26.

Doménech A, Fernández-Garayzábal JF, García JA, Cutuli MT, Blanco M, Gibello A, et al. Association of Pseudomonas anguilliseptica infection with "winter disease" in sea bream, Sparus aurata L. J Fish Dis 1999;22:69-71.

Ellis AE, Dear G, Stewart DJ. Histopathology of Sekiten-byo caused by Pseudomonas anguilliseptica in the European eel, Anguilla anguilla L., in Scotland. J Fish Dis 1983;6:77-9.

Ferguson HW, Collins RO, Moore M, Coles M, MacPhee DD. Pseudomonas anguilliseptica infection in farmed cod, Gadus morhua L. J Fish Dis 2004;27:249-53.

Kusuda R, Dohata N, Fukuda Y, Kawai K. Pseudomonas anguilliseptica infection in striped jack. Fish Pathol 1995;30:121-2.

Lönnström L, Wiklund T, Bylund G. Pseudomonas anguilliseptica isolated from Baltic herring Clupea harengus membras with eye lesions. Dis Aquat Organ 1994;18:143-7.

López-Romalde $S$, Magariños B, Nuñez S, Toranzo AE, Romalde LJ. Phenotypic and genetic characterization of Pseudomonas anguilliseptica strains isolated from fish. J Aquat Anim Health 2003a;15: 39-47.

López-Romalde S, Nuñez S, Toranzo AE, Romalde LJ. Black spot seabream (Pagellus bogaraveo), a new susceptible host for Pseudomonas anguilliseptica. Bull Eur Assoc Fish Pathol 2003b; 23:258-64.

López-Romalde S. Caracterización del Patógeno Emergente en
Acuicultura Marina Pseudomonas anguilliseptica. PhD thesis. Universidad de Santiago de Compostela, Spain. 2005.

Mellergaard S, Dalsgaard I. Disease problems in Danish eel farms. Aquaculture 1987;67:139-46.

Michel C, Bernadet JF, Dinand D. Phenotypic and genotypic studies of Pseudomonas anguilliseptica strains isolated from farmed European eels (Anguilla anguilla) in France. Fish Pathol 1992;27:229-32.

Miyazaki T, Egusa S. Histopathological studies of red spot disease of the Japanese eel (Anguilla japonica) - I. Natural infection. Fish Pathol 1977;12:39-49.

Nakai T, Hanada H, Muroga K. First records Pseudomonas anguilliseptica infection in cultured ayu, Plecoglossus altivelis. Fish Pathol 1985;20:481-4.

Nakai T, Muroga K. Pseudomonas anguilliseptica isolated from European eels (Anguilla anguilla) in Scotland. Fish Pathol 1982; 17:147-50.

Romalde JL, López-Romalde S, Ravelo C, Magariños B, Toranzo AE. Development and validation of a PCR-based protocol for the detection of Pseudomonas anguilliseptica. Fish Pathol 2004;19:33-41.

Stewart DJ, Woldemariam K, Dear G, Mochaba FM. An outbreak of "Sekiten-byo" among cultured European eels, Anguilla anguilla L., in Scotland. J Fish Dis 1983;6:75-6.

Toranzo AE, Baya AM, Robertson BS, Barja JL, Grimes DJ, Hetrick FM. Specificity of the slide agglutination test for detecting bacterial fish pathogens. Aquaculture 1987;61:81-97.

Toranzo AE, Magariños $B$, Romalde JL. A review of the main bacterial fish diseases in mariculture system. Aquaculture $2005 ; 246: 37-$ 61.

Tort L, Padrós F, Rotlant J, Crespo S. Winter syndrome in the gilthead sea bream Sparus aurata. Immunological and histopathological features. Fish Shellfish Immunol 1998;8:37-47.

Wakabayashi H, Egusa S. Characteristics of a Pseudomonas sp. from an epizootic of pond-cultured eels (Anguilla japonica). Nippon Suisan Gakkai Shi 1972;38:577-87.

Wiklund T, Bylund G. Pseudomonas anguilliseptica as a pathogen of salmonid fish in Finland. Dis Aquat Organ 1990;8:13-9. 
G.E. Magi et al. 